\title{
Haplotype structure of the beta adrenergic receptor genes in US Caucasians and African Americans
}

Inna Belfer ${ }^{* 1,2}$, Beata Buzas ${ }^{1,2}$, Catherine Evans ${ }^{1,2}$, Heather Hipp ${ }^{1,2}$, Gabriel Phillips ${ }^{1,2}$, Julie Taubman ${ }^{2}$, Ilona Lorincz ${ }^{1,2}$, Robert H. Lipsky ${ }^{2}$, Mary-Anne Enoch $^{2}$, Mitchell B Max ${ }^{1}$ and David Goldman ${ }^{2}$

\footnotetext{
${ }^{1}$ Pain and Neurosensory Mechanisms Branch, National Institute of Dental and Craniofacial Research, National Institutes of Health, Department of Health and Human Services, Bethesda, MD 20892, USA; ${ }^{2}$ Laboratory of Neurogenetics, National Institute on Alcohol Abuse and Alcoholism, National Institutes of Health, Department of Health and Human Services, Bethesda, MD 20892, USA
}

The beta-adrenergic receptors $(\beta$-AR) are $G$ protein-coupled receptors activated by epinephrine and norepinephrine and are involved in a variety of their physiological functions. Previously, three $\beta$-AR genes ( $A D R B 1, A D R B 2$ and $A D R B 3$ ) were resequenced, identifying polymorphisms that were used in genetic association studies of cardiovascular and metabolic disorders. These studies have produced intriguing but inconsistent results, potentially because the known functional variants: ADRB1 Arg389Gly and Gly49Ser, ADRB2 Arg16Gly and GIn27Glu, and ADRB3 Arg64Trp provided an incomplete picture of the total functional diversity at these genes. Therefore, we created marker panels for each $\beta$-AR gene that included the known functional markers and also other markers evenly spaced and with sufficient density to identify haplotype block structure and to maximize haplotype diversity. A total of 27 markers were genotyped in 96 US Caucasians and 96 African Americans. In both populations and for each gene, a single block with little evidence of historical recombination was observed. For each gene, haplotype captured most of the information content of each functional locus, even if that locus was not genotyped, and presumably haplotype would capture the signal from unknown functional loci whose alleles are of moderate abundance. This study demonstrates the utility of using $\beta$-AR gene haplotype maps and marker panels as tools for linkage studies on $\beta$-AR function.

European Journal of Human Genetics (2005) 13, 341-351. doi:10.1038/sj.ejhg.5201313

Published online 3 November 2004

Keywords: single-nucleotide polymorphism; linkage disequilibrium; haplotype; beta adrenergic receptors, $A D R B 1, A D R B 2, A D R B 3$

\section{Introduction}

The human beta-adrenergic receptors $\left(\beta\right.$-AR) are $\mathrm{G}_{\mathrm{s}}$-protein-coupled receptors that bind catecholamine neurotransmitters and signal transduce by raising intracellular levels of cyclic AMP. ${ }^{1} \beta$-AR are implicated in a variety of catecholamine-mediated physiological functions and in

*Correspondence: Dr Inna Belfer, National Institutes of Health, 12420 Parklawn Drive, Suite 451, MSC 8110, Rockville, MD 20852, USA. Tel: + 1 301402 8323; Fax: + 1301443 8579; E-mail: ibelfer@mail.nih.gov Received 16 March 2004; revised 23 July 2004; accepted 27 August 2004 the pathophysiology of obesity, ${ }^{2}$ asthma ${ }^{3}$ and cardiovascular disorders. ${ }^{4} \beta$-AR have been classified into $\beta 1, \beta 2$ and $\beta 3$ subgroups. $\beta 1$ receptors are expressed in the heart, kidney, blood vessels and regulate heart rate and vascular tone. $\beta 2$ receptors are widely distributed in the respiratory tract, and relax smooth muscle in small airways. $\beta 3$ receptors are found mainly in adipose tissue, where they stimulate lipolysis and thermogenesis. ${ }^{5}$ Genes encoding the three $\beta$-AR subtypes (ADRB1, hCG39839; ADRB2, hCG36934 and ADRB3, hCG21141) are located on chromosomes 10, 5 and 8, respectively. ADRB1 and ADRB2 are 
nonintronic, and are 3.2 and $3.4 \mathrm{~kb}$, respectively. ADRB3 has one intron and is $3.7 \mathrm{~kb}$ in length.

Functional loci have been identified at each of the $\beta$-AR genes. Two abundant ADRB1 missense variants Ser49Gly and Gly389Arg ${ }^{6}$ alter in vitro receptor coupling ${ }^{7}$ but have no clear in vivo significance. Some positive results were reported using these markers in linkage studies of cardiomyopathy, ${ }^{8}$ heart and renal failure, ${ }^{7,9}$ and hypertension. ${ }^{10}$ However, no relationship was detected to the response of healthy subjects to drugs acting through the $\beta 1-\mathrm{AR}^{11}$ nor in the hemodynamic response of hypertensive subjects to chronic $\beta 1$-AR blockade. ${ }^{12}$ Two obesity studies with the Gly389Arg marker yielded conflicting results. ${ }^{13,14}$

Within the coding region of $A D R B 2$, nine SNPs were identified, ${ }^{15}$ five of which are synonymous. Missense substitutions were Arg16Gly, Gln27Glu, Val34Met, and Thr164Ile. ${ }^{16,17}$ Among them, two common alleles have been shown to be functional in vitro: Gly16 leads to enhanced agonist-mediated downregulation, and Glu27 reduces such regulation. ${ }^{18}$ These polymorphisms have been associated with a variety of $\beta$-AR-related phenotypes, but association results have been inconsistent across different studies. Arg16Gly was associated with obesity, ${ }^{19,20}$ diabetes $^{21}$ and cystic fibrosis, ${ }^{22}$ but not with plasma norepinephrine concentration ${ }^{23}$ or agonist-induced beta 2AR desensitization. ${ }^{24}$ Evidence regarding the Arg16Gly polymorphism's relationship with asthma is conflicting. ${ }^{25,26}$ Gln27Glu was associated with hypertriglyceride$\mathrm{mia}^{27}$ and obesity in Spanish men ${ }^{28}$ but not in the Tongan population. ${ }^{29}$

ADRB3 Trp64Arg is located in the first intracellular loop of the receptor. Arg64 has higher allele frequencies in Pima Indians [0.31] as compared to Mexican Americans [0.13], African Americans [0.12], and Caucasians [0.08 ${ }^{30}$ supporting the idea that this variant could impair activation of thermogenesis in adipose cells, contributing to the high frequency of obesity and adult onset diabetes in the Pima Indians. ${ }^{31}$ However, the linkage studies are contradictory. ${ }^{32}$

Taken together, this evidence illustrates that a consistent picture of $\beta$-AR genotype-phenotype relationships has yet to emerge. Other functional loci may be present, including polymorphisms which are known but which have not yet been recognized to be functional. A haplotype approach combining known functional polymorphisms with a series of loci chosen for haplotype informativeness could comprehensively capture the potential information content on $\beta$-AR functional variants of moderate abundance. ${ }^{33}$ In this study, we report a haplotype map for each of the $\beta$-AR genes for two populations, American Caucasians and African Americans, by genotyping a panel of SNP markers and the known functional polymorphisms in these populations. For each gene, we also describe marker panels that maximize haplotype information content.

\section{Materials and methods Participants}

A total of 192 unrelated subjects were genotyped, including 96 individuals from each of two populations: US Caucasians and African Americans. Informed consent was obtained according to human research protocols approved by the human research committees of the recruiting institutes, including the National Institute on Alcohol Abuse and Alcoholism, National Institute of Mental Health and Rutgers University. All participants had been psychiatrically interviewed and none had been diagnosed with a psychiatric disorder.

\section{SNP markers}

The physical position and frequency of minor alleles ( $>0.05)$ from a commercial database (Celera Discovery System, CDS, September, 2003) were used to select SNPs (including known nonsynonymous substitutions). $5^{\prime}$ nuclease assays (vide infra) were designed for seven ADRB1, 11 $A D R B 2$ and nine $A D R B 3$ SNPs and optimized. These markers were nearly equally spaced and covered the entire genes plus $2.5-6 \mathrm{~kb}$ upstream and $2.5-6 \mathrm{~kb}$ downstream from each gene.

\section{Genomic DNA}

Genomic DNA was extracted from lymphoblastoid cell lines, diluted to a concentration of $10 \mathrm{ng} / \mu \mathrm{l}$. Aliquots of $1 \mu \mathrm{l}$ were dried in 384-well plates.

\section{Polymerase chain reaction (PCR) amplification} Genotyping was performed by the $5^{\prime}$ nuclease method ${ }^{34}$ using fluorogenic allele-specific probes. Oligonucleotide primer and probe sets were designed based on gene sequence from the CDS, September 2003. Primers and detection probes for each locus in each gene are listed in Table $1 \mathrm{a}-\mathrm{c}$.

Reactions were in a $5 \mu \mathrm{l}$ volume containing $2.375 \mu \mathrm{l} \mathrm{TE}$, $2.5 \mu$ Master Mix (ABI, Foster City, CA, USA) with AmpliTaq Gold ${ }^{\circledR}$ DNA Polymerase, dNTPs, Gold Buffer and $\mathrm{MgCl}_{2}, 10 \mathrm{ng}$ genomic DNA, $900 \mathrm{nM}$ of each forward and reverse primer and $100 \mathrm{~nm}$ of each reporter and quencher probe. DNA was incubated at $50^{\circ} \mathrm{C}$ for $2 \mathrm{~min}$ and at $95^{\circ} \mathrm{C}$ for $10 \mathrm{~min}$, and amplified on an ABI 9700 device for 40 cycles at $95^{\circ} \mathrm{C}$ for $30 \mathrm{~s}$ and $60^{\circ} \mathrm{C}$ for $75 \mathrm{~s}$. Allele-specific signals were distinguished by measuring end point 6-FAM or VIC fluorescence intensities at 508 and $560 \mathrm{~nm}$, respectively, and genotypes were generated using Sequence Detection V.1.7 (ABI).

Genotyping error rate was directly determined by regenotyping $25 \%$ of the samples, randomly chosen, for each locus. The overall error rate was $<0.005$. Genotype completion rate was 0.99 . 
Table 1 Primer and probe sequences for $5^{\prime}$ nuclease genotyping

\begin{tabular}{|c|c|c|}
\hline SNP & Primers and probes & Sequences \\
\hline \multicolumn{3}{|c|}{ (a) Of seven ADRB1 markers } \\
\hline 1 & Assay on Demand \# 2648572 (ABI, Ca) & \\
\hline \multirow[t]{4}{*}{2} & Forward primer & TCTCAAAAAAATAAAAAGAAAGAAGCCAGGAG \\
\hline & Reverse primer & GGAGACTACACCCCAAGTTATCCAA \\
\hline & Allele 1 probe (FAM) & CAGGCTTGCAGTGAC \\
\hline & Allele 2 probe (VIC) & TCTCAGGCTTTCAGTGAC \\
\hline \multirow[t]{4}{*}{3} & Forward primer & CCGCCCGCCTCGTT \\
\hline & Reverse primer & СGСТGTССАСТGСTGAGA \\
\hline & Allele 1 probe (FAM) & CAGCGAAGGCCCCGA \\
\hline & Allele 2 probe (VIC) & CCAGCGAAAGCCСCGA \\
\hline \multirow[t]{4}{*}{4} & Forward primer & CCGCAGCCCCGACTTC \\
\hline & Reverse primer & GCCGGTCTCCGTGGGT \\
\hline & Allele 1 probe (FAM) & CTTCCAGGGACTGC \\
\hline & Allele 2 probe (VIC) & TTCCAGCGACTGCT \\
\hline \multirow[t]{4}{*}{5} & Forward primer & АCATTTTCACAGCCGGATTCA \\
\hline & Reverse primer & TСТTСАGTCAAGTGCAGCAGATG \\
\hline & Allele 1 probe (FAM) & AGGTGTTCTAGATTACTT \\
\hline & Allele 2 probe (VIC) & AGGTGTTCTAGACTACTT \\
\hline \multirow[t]{4}{*}{6} & Forward primer & СTTGTTAAGCACATTTCСTAGCTTATGTT \\
\hline & Reverse primer & GTGCAGAATTTCTGTCTGGCAATTT \\
\hline & Allele 1 probe (FAM) & CAGAGGAACGGGCACA \\
\hline & Allele 2 probe (VIC) & CCAGAGGAACAGGCACA \\
\hline \multirow[t]{4}{*}{7} & Forward primer & GTTGTTCCACCTTCAACTATTTGCA \\
\hline & Reverse primer & GGCCATCTGCTTGAAAGAGTTTT \\
\hline & Allele 1 probe (FAM) & ATTTGTGGGAATTGT \\
\hline & Allele 2 probe (VIC) & TGATTTGTGAGAATTGT \\
\hline
\end{tabular}

(b) Of 11 ADRB2 markers

1

2

3

4

5

6

7

8

10

11
Assay on Demand \# 2084740 (ABI, Ca) Forward primer

Reverse primer

Allele 1 probe (FAM)

Allele 2 probe (VIC)

Forward primer

Reverse primer

Allele 1 probe (FAM)

Allele 2 probe (VIC)

Forward primer

Reverse primer

Allele 1 probe (FAM)

Allele 2 probe (VIC)

Forward primer

Reverse primer

Allele 1 probe (FAM)

Allele 2 probe (VIC)

Forward primer

Reverse primer

Allele 1 probe (FAM)

Allele 2 probe (VIC)

Forward primer

Reverse primer

Allele 1 probe (FAM)

Allele 2 probe (VIC)

Forward primer

Reverse primer

Allele 1 probe (FAM)

Allele 2 probe (VIC)

Assay on Demand \# 2084766 (ABI, Ca)

Forward primer

Reverse primer

Allele 1 probe (FAM)

Allele 2 probe (VIC)

Forward primer

Reverse primer

\author{
CAAGTTGTTGTGTAGGATATTGGCAATT \\ GTGCTTTGAGGGCCACTGA \\ CGAATCAGAAATTTA \\ CCGAATCAAAAATTTA \\ TCCAGTTCAAATGAAGCATTAACTCTCT \\ CCAGCAGAGGAGTTCGAGTAG \\ ATGTGAACAGTATGCAGTG \\ ATGTGAACAGTAAGCAGTG \\ TGAGGTGAGTGTATTTTGAAAACTATGTGA \\ TGCAAGACAGATGCCTTAGAAAACA \\ ACAAATATGAATTAAGGATCTA \\ CACAAATATGAATTAAAGATCTA \\ AACCACTAAGTAATTTATGTAAACTTCGCT \\ TAAGAAATATGAAAATGCTTTTGCTCAT \\ CACACAAGTGTAGTTTG \\ TCACACAAGTATAGTTTG \\ GTAAGTCACAGACGCCAGATGGT \\ ССТTTCATCTGCTGGATAGTTTGTT \\ ATGGCACAACCCG \\ ACATGGCGCAACC \\ CGGCAGCGCCTTCTTG \\ TGCGTGACGTCGTGGTC \\ ACCCAATGGAAGCC \\ CACCCAATAGAAGCC \\ ССТTCTTGCTGGCACCCAAT \\ TGCCCACCACCCACAC \\ CGTCCCTTTGCTGCGT \\ CTCGTCССTTTCCTGCGT \\ CCTGCGCAGGTCTTCTTTG \\ GTGTTGCCGTTGCTGGAGTA \\ CTATGGCAATGGC \\ AGGCCTATGGGAATG \\ TGAGAAATTCTGGTGTTTTGTGAATAA \\ GGTGGTGGGTGGGAGGTT
}


Table 1 Continued

\begin{tabular}{|c|c|c|}
\hline SNP & Primers and probes & Sequences \\
\hline & $\begin{array}{l}\text { Allele } 1 \text { probe (FAM) } \\
\text { Allele } 2 \text { probe (VIC) }\end{array}$ & $\begin{array}{l}\text { TGAAAAGAGGCCCC } \\
\text { TGAAAAGAGCCCCC }\end{array}$ \\
\hline \multicolumn{3}{|c|}{ (c) Of nine $A D R B 3$ markers } \\
\hline 1 & Assay on Demand \# 3273558 (ABI, Ca) & \\
\hline 2 & $\begin{array}{l}\text { Forward primer } \\
\text { Reverse primer } \\
\text { Allele } 1 \text { probe (FAM) } \\
\text { Allele } 2 \text { probe (VIC) }\end{array}$ & $\begin{array}{l}\text { AGAGCCTGGAGAACACTAAGGT } \\
\text { GTGAGTGCTTAGGGCAAAGAGA } \\
\text { CCATTCCTTCTGCCACC } \\
\text { TTCСАTTCСTTTTGCСАСC }\end{array}$ \\
\hline 3 & Assay on Demand \# 3273557 (ABI, Ca) & \\
\hline 4 & Assay on Demand \# 3273556 (ABI, Ca) & \\
\hline 5 & $\begin{array}{l}\text { Forward primer } \\
\text { Reverse primer } \\
\text { Allele } 1 \text { probe (FAM) } \\
\text { Allele } 2 \text { probe (VIC) }\end{array}$ & $\begin{array}{l}\text { GCTTCCCGACCCTGAGC } \\
\text { GCAGCCCAGGCTITGC } \\
\text { TCTGCCCCGGTTAC } \\
\text { CСTCTGACССGGTTAC }\end{array}$ \\
\hline 6 & Assay on Demand \# 2215549 (ABI, Ca) & \\
\hline 7 & $\begin{array}{l}\text { Forward primer } \\
\text { Reverse primer } \\
\text { Allele } 1 \text { probe (FAM) } \\
\text { Allele } 2 \text { probe (VIC) }\end{array}$ & $\begin{array}{l}\text { CAACTCCCTCGGTGCCA } \\
\text { CCCCTTIAAGCGTCGCTACTC } \\
\text { CTCCCCCGAGAGCG } \\
\text { TCCCCCAAGAGCG }\end{array}$ \\
\hline 8 & $\begin{array}{l}\text { Forward primer } \\
\text { Reverse primer } \\
\text { Allele } 1 \text { probe (FAM) } \\
\text { Allele } 2 \text { probe (VIC) }\end{array}$ & $\begin{array}{l}\text { CTGGGAGTTAGGAAGGTTGCA } \\
\text { GGAGACGAGGCTGGTTCTIT } \\
\text { CTAAAATTATCCCCAAGGAA } \\
\text { CTAAAATTATCCCGAAGGAA }\end{array}$ \\
\hline 9 & $\begin{array}{l}\text { Forward primer } \\
\text { Reverse primer } \\
\text { Allele } 1 \text { probe (FAM) } \\
\text { Allele } 2 \text { probe (VIC) }\end{array}$ & $\begin{array}{l}\text { CTITGTTCTGTGCCCTTGGAA } \\
\text { GGCCTGAACTCAGTGCATT } \\
\text { ACAGACGCTGCCTG } \\
\text { CACAGATGCTGCCTG }\end{array}$ \\
\hline
\end{tabular}

\section{Haplotype analysis}

Haplotype frequencies were estimated using a Bayesian approach implemented with PHASE. ${ }^{35}$ These frequencies closely agreed with results from a maximum likelihood method implemented via an expectation-maximization (EM) algorithm. ${ }^{36}$ Haploview version 2.0.2 (Whitehead Institute for Biomedical Research, USA) was used to produce LD matrices.

\section{Results and discussion}

Of a total of 27 markers in three $\beta$-AR genes, 23 were polymorphic both in US Caucasians and African Americans. ADRB3 marker \#2 (rs4999) was monomorphic in Caucasians, and ADRB3 markers 7-9 (rs4993, rs802162 and rs13258937) were monomorphic in both populations. Dramatic interpopulation differences in allele frequencies were observed for many of the markers. Allele frequencies of all markers and their locations in the genes are shown in Table 2a-c. For ADRB1, two functional nonsynonymous polymorphisms (Ser49Gly and Ala389Gly) are located in the exon, one marker is located in the gene $3^{\prime}$ UTR region, and the rest of the markers are in the intergenic region upstream and downstream of ADRB1 (Figure 1a). For
$A D R B 2$, two functional nonsynonymous polymorphisms (Arg16Gly and Gln27Glu) and two synonymous polymorphisms are located in the exon, one marker is located in the gene $5^{\prime}$ UTR region, and the rest of the markers are in the intergenic region upstream and downstream of $A D R B 2$ (Figure 1b). For $A D R B 3$, one functional nonsynonymous polymorphism (Arg64Trp) is located in exon 1, one marker is located in the $5^{\prime}$ UTR region (exon 1), two markers are located in the gene $3^{\prime}$ UTR region (exon 2), and the rest of the markers are in the intronic sequence and intergenic region upstream and downstream of $A D R B 3$ (Figure 1c).

Within the $A D R B 1, A D R B 2$ and $A D R B 3$ regions, a single conserved haplotype block spanned each gene in both Caucasians and African Americans (Figure 2a-c) and the block boundaries extend beyond the region we have evaluated. In African Americans, the ADRB2 block may be smaller; the first and last SNPs were in lower linkage disequilibrium (LD) $\left[D^{\prime}<0.8\right]$ with all other markers. Definition of haplotype blocks and block boundaries is inexact. Isolated nucleotide substitutions can occur within nonrecombined blocks. On the other hand, some disruptions of LD occurring within blocks are attributable to low allele frequencies that lead to increased variance in estimation of LD. We discounted low $D^{\prime}$ values which might have originated from this cause. In the $A D R B 1$, 
Table 2 Locations and allelic frequencies in 96 individuals from each of two populations

\begin{tabular}{|c|c|c|c|c|c|}
\hline SNP ID & SNP ID & & Position & & Allelic frequency (for allele 2) \\
\hline$(C D S)$ & $(N C B I)$ & Variation & $(C D S)$ & Location & US Caucasians African Americans \\
\hline
\end{tabular}

(a) Of seven ADRB1 markers

$\begin{array}{lllll}1^{\mathrm{a}, \mathrm{b}} & 2648572 & \text { rs2773469 } & \mathrm{G}>\mathrm{A} & 109526266 \\ 2^{\mathrm{a}, \mathrm{b}} & 11743658 & \text { rs2053095 } & \mathrm{G}>\mathrm{T} & 109528966 \\ 3 & 8898508 & \text { rs1801252 } & \text { Gly49Ser }(\mathrm{G}>\mathrm{A}) & 109531407 \\ 4^{\mathrm{a}, \mathrm{b}} & 27859421 & \text { rs1801253 } & \text { Gly389Ala }(\mathrm{G}>\mathrm{C}) & 109532428 \\ 5^{\mathrm{b}} & 2648569 & \mathrm{rs} 3813719 & \mathrm{~T}>\mathrm{C} & 109534254 \\ 6^{\mathrm{b}} & 16149641 & \mathrm{rs} 2183378 & \mathrm{G}>\mathrm{A} & 109536263 \\ 7^{\mathrm{b}} & 2648567 & \text { rs7920400 } & \mathrm{G}>\mathrm{A} & 109538512\end{array}$

$5^{\prime}$ Intergenic
$5^{\prime}$ Intergenic
Exon
Exon
$3^{\prime}$ UTR/exon
$3^{\prime}$ Intergenic
$3^{\prime}$ Intergenic

144279479

144281317

144283535

144285812

144286058

144287102

$G>A$

A $>$ G Gly16Arg

$(G>A)$ Gln27Glu

$(\mathrm{G}>\mathrm{C})$ Leu84Leu

$(\mathrm{A}>\mathrm{G})$ Gly351Gly

$(C>G)$

144288490

144288523

144288696

144289497

144293909

$\mathrm{G}>\mathrm{C}$

5' Intergenic
$5^{\prime}$ Intergenic
$5^{\prime}$ Intergenic
$5^{\prime}$ Intergenic
$5^{\prime}$ Intergenic
$5^{\prime}$ UTR/Exon
Exon
Exon
Exon
Exon
$3^{\prime}$ Intergenic

0.777
0.664
0.432
0.42
0.573
0.563
0.341
0.386
0.239
0.696
0.836

0.41

0.772

0.412

0.41
0.571

0.577

0.448

0.186

0.37

0.618

0.605

(c) Of nine $A D R B 3$ markers

$\begin{array}{llll}1^{\mathrm{a}, \mathrm{b}} & 3273558 & \mathrm{rs} 9694197 & \mathrm{G}>\mathrm{A} \\ 2^{\mathrm{b}} & 12106155 & \mathrm{rs} 4999 & \mathrm{C}>\mathrm{T} \\ 3^{\mathrm{b}} & 3273557 & \mathrm{rs} 4998 & \mathrm{G}>\mathrm{C} \\ 4 & 3273556 & \mathrm{rs} 2071493 & \mathrm{~T}>\mathrm{C} \\ 5 & 12106153 & \mathrm{rs} 4997 & \mathrm{C}>\mathrm{A} \text { Trp64Arg } \\ 6 & 2215549 & \mathrm{r} 4994 & (\mathrm{~T}>\mathrm{C}) \\ 7 & 12106148 & \mathrm{rs} 4993 & \mathrm{G}>\mathrm{A} \\ 8 & 8844728 & \mathrm{rs} 802162 & \mathrm{C}>\mathrm{C} \\ 9 & 2451694 & \mathrm{rs} 13258937 & \mathrm{C}>\mathrm{T}\end{array}$

$\begin{array}{ll}36771802 & 3^{\prime} \text { Intergenic } \\ 36773088 & 3^{\prime} \text { UTR/Exon 2 } \\ 36773195 & 3^{\prime} \text { UTR/Exon 2 } \\ 36773562 & \text { Intron 1 } \\ 36774478 & \text { Intron 1 } \\ 36775507 & \text { Exon 1 } \\ 36775879 & 5^{\prime} \text { UTR/Exon 1 } \\ 36778541 & 5^{\prime} \text { Intergenic } \\ 36780439 & 5^{\prime} \text { Intergenic }\end{array}$

0.918
0
0.907
0.919
0.077
0.081
1
0
0$$
0
$$

Markers \#3 and \#4 are known functional polymorphisms.

Physical locations are from the Celera Discovery system [CDS] database, September 2003. NCBI ID's are from the National Center for Biotechnology Information database, November 2003.

andicates tag SNPs for Caucasians.

bIndicates tag SNPs for African Americans.

Markers \#7 and \#8 are known functional polymorphisms.

Marker \#6 is known functional polymorphism; marker \#2 is monomorphic in Caucasians, and \#\#7-9 are monomorphic in both Caucasians and African Americans and then excluded from LD matrix (Figure 2c).

$A D R B 2$ and $A D R B 3$ haplotype block regions, $D^{\prime}$ was generally $>0.80$ from one end of the region to the other. Average $D^{\prime}$ values within haplotype blocks in Caucasians and African Americans were, respectively, ADRB1: 0.98 and 0.84, ADRB2: 0.98 and 0.87, ADRB3: 1.00 and 0.74. Median $D^{\prime}$ values within the haplotypes blocks from both Caucasians and African Americans were high: ADRB1: 1.00 and 1.00, ADRB2: 1.00 and 1.00, and ADRB3: 1.00 and 0.93, indicating that most pairs of loci within these regions are in very high $L D$.

Haplotype frequencies for ADRB1, ADRB2 and ADRB3 in both populations are shown in Table $3 a-c$. For each population and haplotype block, 2-5 common (frequency $\geqslant 0.05$ ) haplotypes accounted for most of the total: $88-$ $100 \%$ of Caucasian and $88-96 \%$ of African-American haplotypes. For US Caucasians and African Americans, the numbers of common (frequency $\geqslant 0.05$ ) haplotypes were: in ADRB1, 3 and 5; in ADRB2, 4; in ADRB3, 2 and 4, respectively. Population differences in haplotype frequencies are clearly illustrated in Figure $3 \mathrm{a}-\mathrm{c}$.

The marker panels we genotyped were sufficient to capture diversity in all blocks in the two populations we studied. We evaluated haplotype diversity within each block by successively subtracting SNPs from the haplotypes 

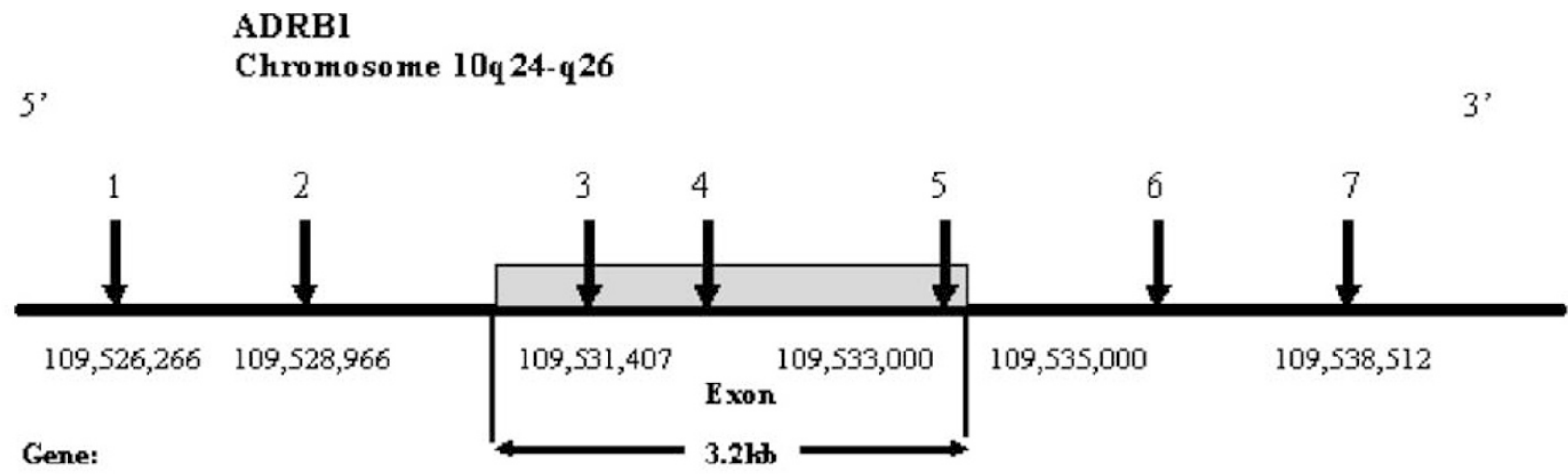

\section{$12.2 \mathrm{~kb}$}

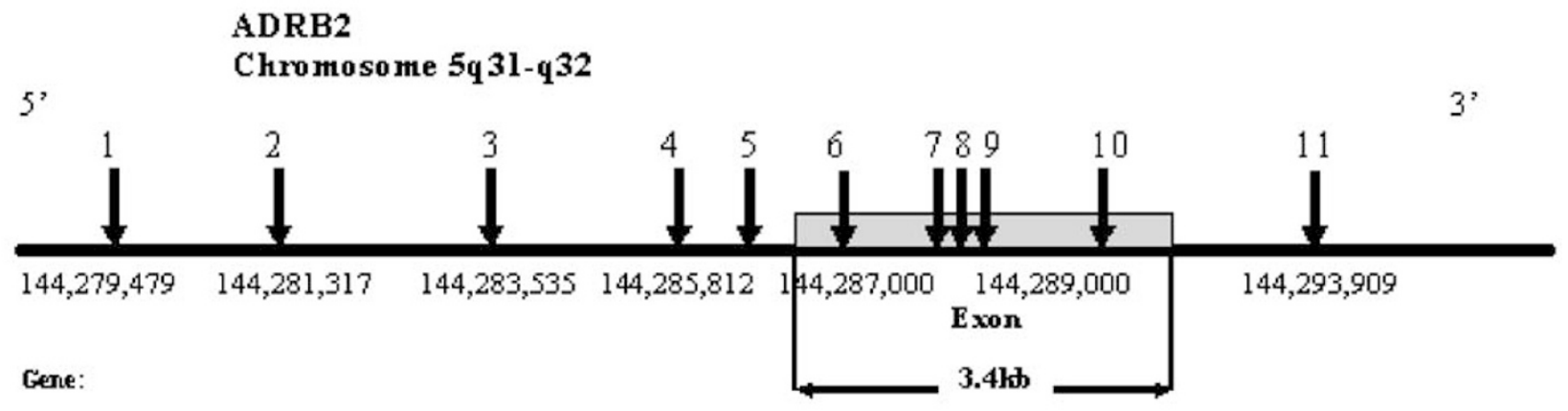

$14.4 \mathrm{~kb}$

ADRB3

Chromosome 8p 12-p11.2

5 ,

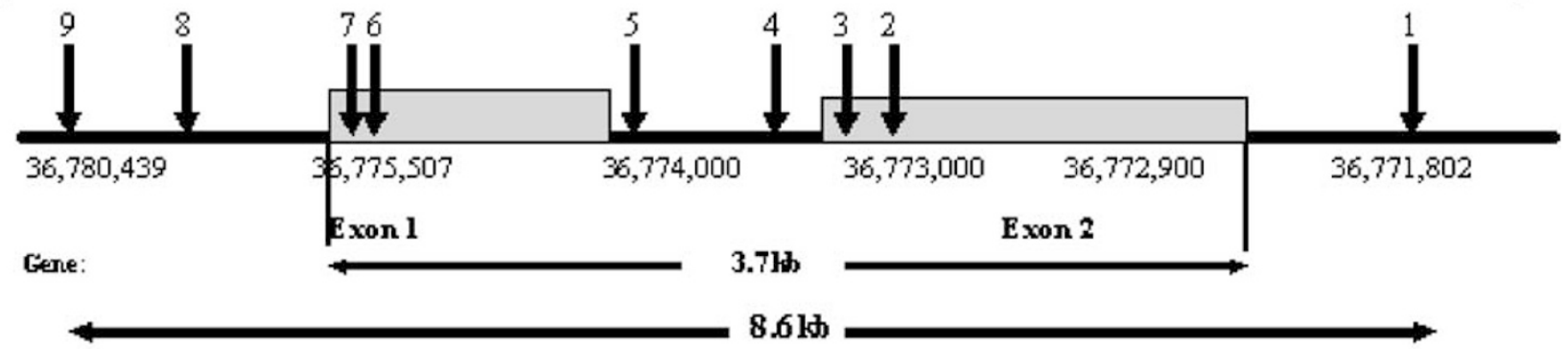

*ADRB3 is transcribed in the reverse direction*

Figure 1 Locations of single-nucleotide polymorphisms genotyped in ADRB1, ADRB2 and ADRB3. Coding exons are shown as solid blocks. Physical locations are from the Celera Discovery System [CDS] database, September 2003. *ADRB3 is transcribed in the reverse direction.

to evaluate the increment/decrement in diversity contributed by each SNP. SNPs were serially subtracted in that order that minimized the decrement in diversity at each step, and until only a single SNP (ie the SNP with the highest heterozygosity) remained. The chosen measure of diversity (haplotype frequencies and diplotype heterozygosity) 

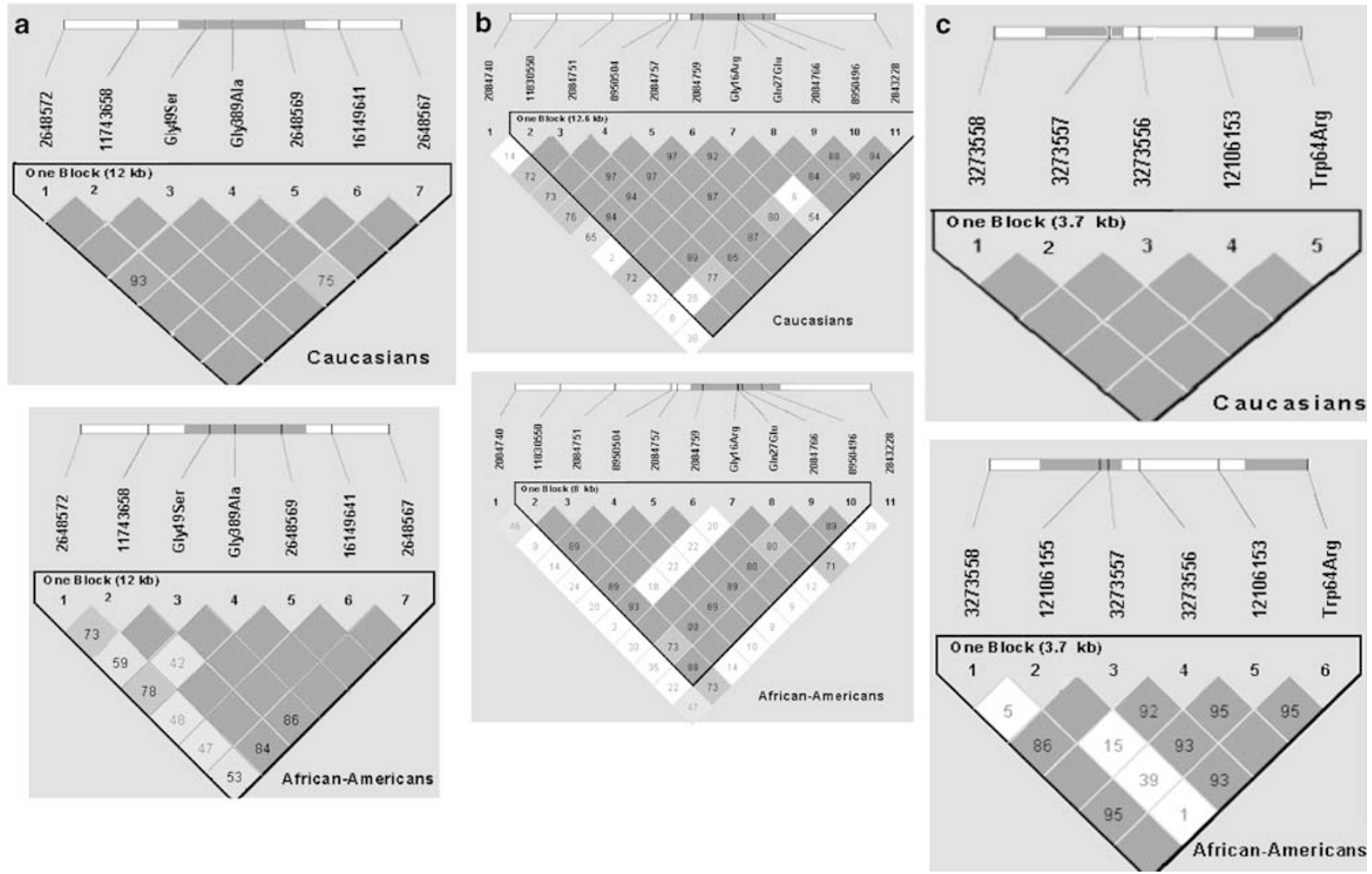

Figure 2 (a-c) Haplotype block organization of $A D R B 1, A D R B 2$ and $A D R B 3$. Each box represents \% $L D\left[D^{\prime}\right]$ between pairs of markers, as generated by Haploview (Whitehead Institute for Biomedical Research, USA). $D^{\prime}$ is color coded, red box indicating complete [1.00] $D^{\prime}$ between locus pairs. ${ }^{*} A D R B 3$ marker \#2, monomorphic in Caucasians, is excluded from the Caucasian haplotype map, but included, for comparability to African Americans, in all haplotypes (see Table 3c).

was recalculated for each size SNP panel $[n, n-1, \ldots, 1]$. At some point for each haplotype block and for each population, adding or subtracting a SNP does not appreciably alter diversity, as shown in Figure 4, panels A-C. For $A D R B 1$ and $A D R B 2$, haplotype diversity was highest in African Americans. A similar number of markers (2-4) was sufficient to capture maximum diversity in either population. This number represents an optimal panel, itself derived from the larger panel of SNP markers we genotyped. The minimum SNP set necessary to maximize haplotype diversity was also determined using SNPTagger. $^{37}$ The SNPs that constitute this minimal set are indicated in Table $2 \mathrm{a}-\mathrm{c}$.

For each $\beta$-AR gene, extensive amounts of resequencing have been performed and missense polymorphisms are known within each gene. ${ }^{38-43}$ However, resequencing has been largely confined to the coding regions and to only a few populations. Although a complete inventory of common missense variants may be available in Caucasians and African Americans, unknown loci affecting function may be present, and some loci that are known may have unrecognized functional significance. Individual SNP loci provided some ability to capture information on the missense polymorphisms known at each gene $\left(r^{2}\right.$ values ranged in Caucasians and African Americans, respectively: ADRB1 Gly49Ser: $0.04-1.00$ and 0.13-0.71, ADRB1 Gly389Ala: $0.03-0.84$ and $0.03-0.59$, ADRB2 Gly16Arg: 0.01-0.83 and 0.06-0.5, ADRB2 Gln27Glu: 0.14-0.94 and 0.02-0.23, ADRB3 Trp64Arg: 1.00 and 0.01-0.95, and as shown in Table $4 \mathrm{a}-\mathrm{c}$ ). Haplotypes enabled high sensitivity of detection of the missense substitutions (when a missense allele was present a particular haplotype(s) was present) and specificity of detection (when a haplotype(s) was present the missense allele was present). For each of the three $\beta$-AR genes, the haplotype was capable of capturing all or almost all the information provided by directly genotyping the missense loci, in either population (Table 5a, b). It is therefore likely that the SNP panels covering $\beta$-AR gene regions would capture information on unknown functional alleles. Certainly, genotyping of 
a

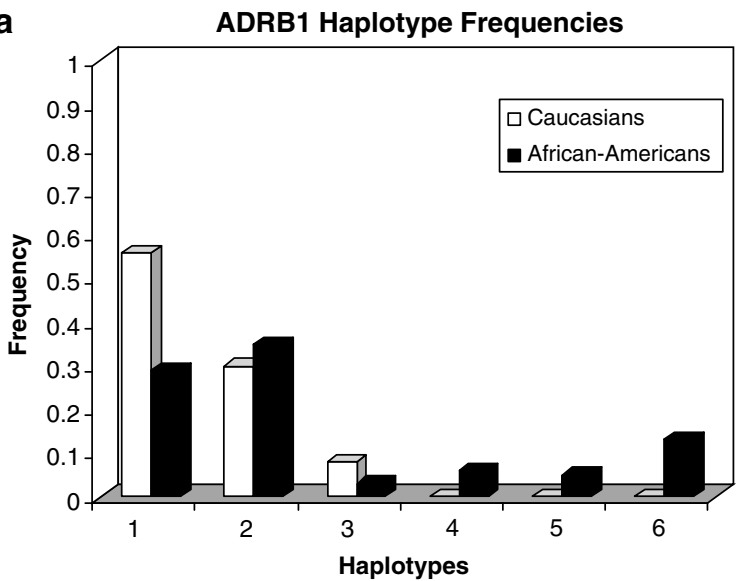

b

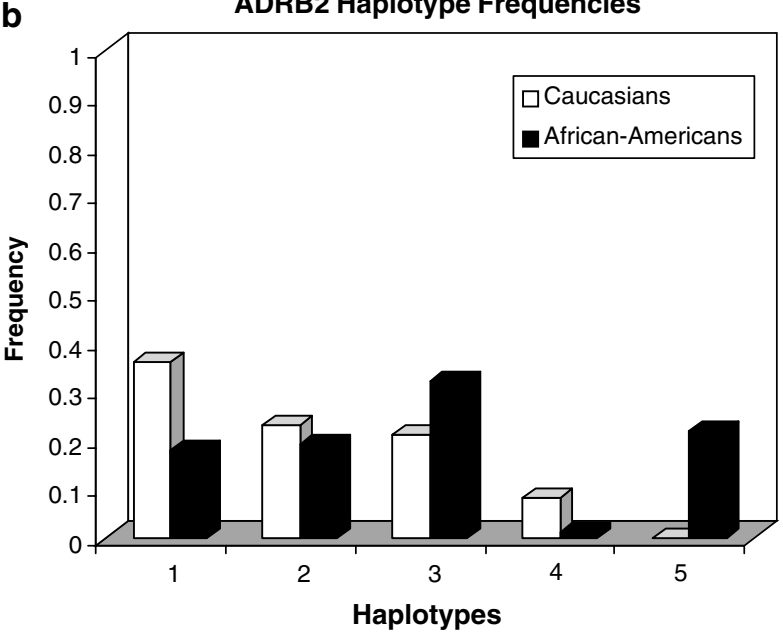

C

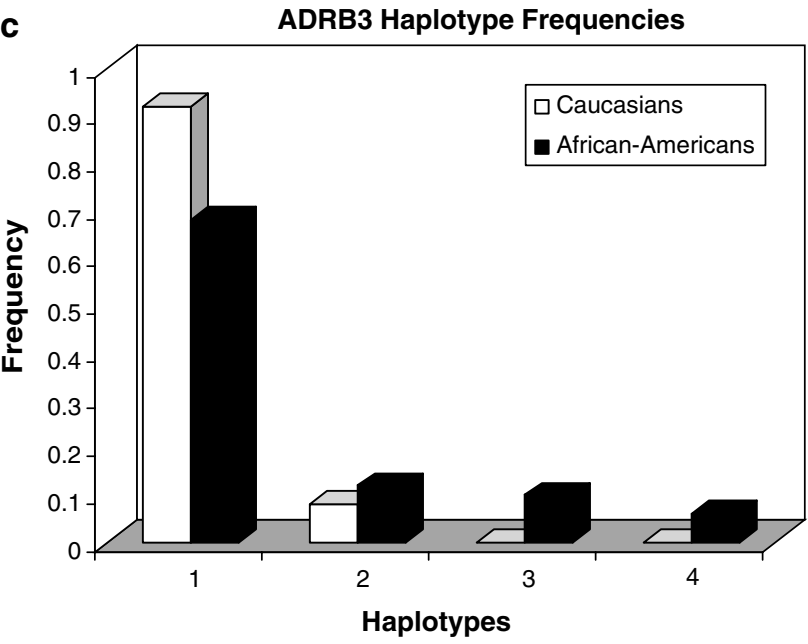

Figure $3(\mathbf{a}-\mathbf{c})$ Frequencies of common $\beta$-AR haplotypes in US Caucasians and African Americans.
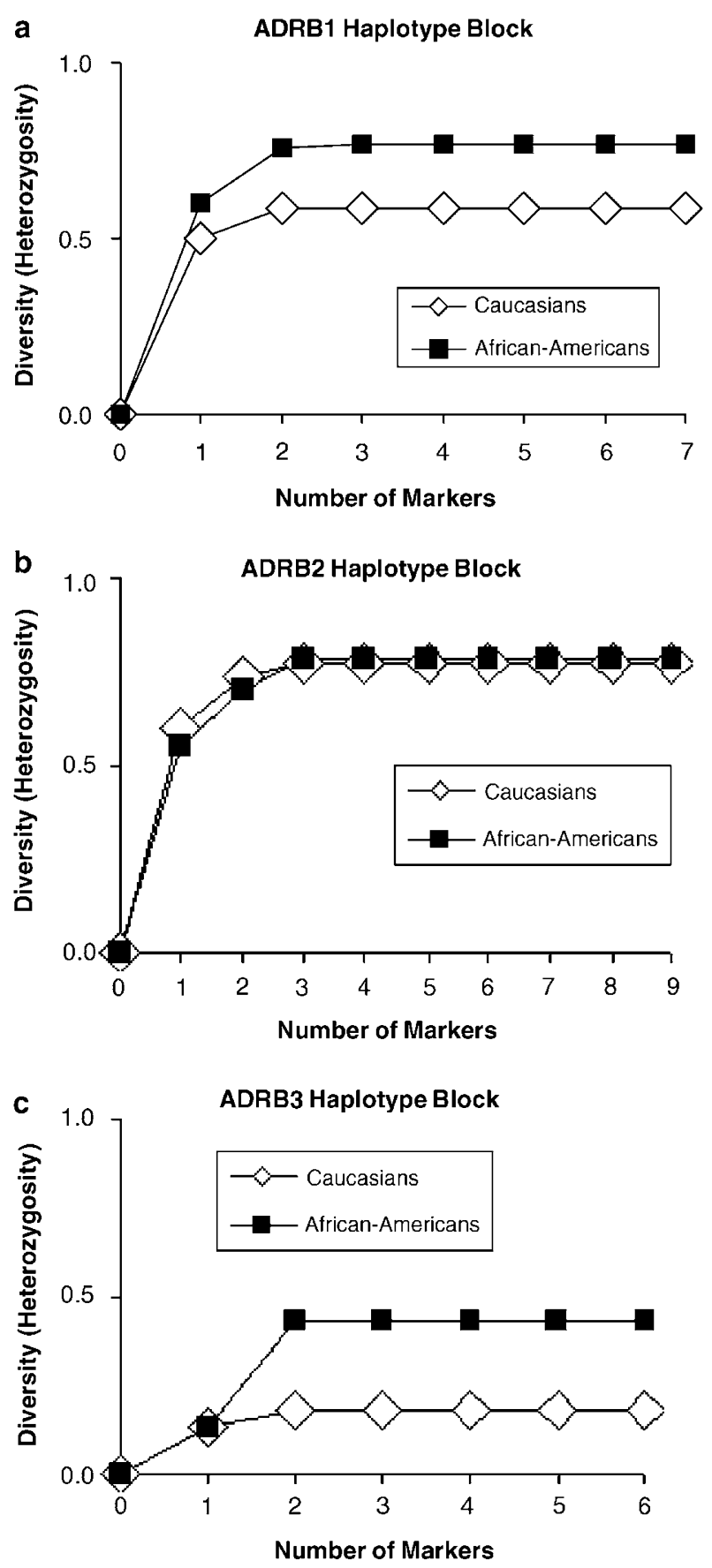

Figure $4(\mathbf{a}-\mathbf{c})$ Effect of successive subtraction/addition of SNPs on $\beta$-AR haplotype diversity in two populations. SNPs were successively subtracted from haplotypes in such a way as to minimize loss of diversity (diplotype heterozygosity, $Y$-axis). Panel (a) ADRB1, panel (b) ADRB2 and panel (c) $A D R B 3$. For each block, marker panels are sufficient to maximize diversity, and diversity can in fact be maximized with 2-4 optimal markers. For each haplotype panel, addition of the functional $\beta$-AR locus (or loci) yields no further increment in diversity. 
polymorphisms that affect gene expression and/or function is highly important in association/linkage studies. However, there is a possibility that an unrecognized functional locus contributes to a phenotype. The focus of

Table 3 Frequencies of haplotypes

Frequencies

\# Common haplotypes

US Caucasians African Americans

\begin{tabular}{llll}
\hline (a) & ADRB1 constructed from seven markers & \\
1 & 1222212 (GTACCGA) & 0.56 & 0.29 \\
2 & 2221212 (ATAGCGA) & 0.30 & 0.35 \\
3 & 1112121 (GGGCTAG) & 0.08 & 0.03 \\
4 & 1121212 (GGAGCGA) & 0 & 0.06 \\
5 & 1112212 (GGGCCGA) & 0 & 0.05 \\
6 & 1112211 (GGGCCGG) & 0 & 0.13
\end{tabular}

(b) ADRB2 constructed from nine markers

$\begin{array}{llll}1 & 222111212 \text { (AAAGAGCAG) } & 0.36 & 0.18 \\ 2 & 111222112 \text { (GTGAGAGAG) } & 0.23 & 0.19 \\ 3 & 211221121 \text { (ATGAGGGGC) } & 0.21 & 0.32 \\ 4 & 111222111 \text { (GTGAGAGAC) } & 0.08 & 0.01 \\ 5 & 222112112 \text { (AAAGAAGAG) } & 0 & 0.22\end{array}$

(c) $A D R B 3$ constructed from six markers

$\begin{array}{llll}1 & 212211 \text { (ACCCCT) } & 0.92 & 0.68 \\ 2 & 111122 \text { (GCGTAC) } & 0.08 & 0.12 \\ 3 & 211211 \text { (ACGCCT) } & 0 & 0.10 \\ 4 & 221211 \text { (ATGCCT) } & 0 & 0.06\end{array}$

$(1=$ allele $1 ; 2=$ allele 2$)$

Marker \#3 is Gly49Ser ( $1=$ Gly, $2=$ Ser $)$ and marker \#4 is Gly389Ala $(1=$ Gly, 2 =Ala).

Marker \#7 is Gly16Arg ( $1=$ Gly, $2=$ Arg) and marker \#8 is Gln27Glu $(1=\mathrm{Gln}, 2=\mathrm{Glu})$.

Markers \#1 and \#11 are not part of the African-American haplotype block and thus were excluded.

Marker \#6 is Trp64Arg ( $1=\operatorname{Trp}, 2=$ Arg). Markers \#7, \#8 and \#9 were monomorphic in both Caucasians and African Americans and were thus excluded. the haplotype-based approach to analyzing case-control populations has been to detect the effects of every functional locus, known or unknown.

For the $\beta$-AR genes, we have created multilocus SNP panels to define haplotype structure across each gene region. Each panel is sufficient to capture the signal of the moderately abundant missense alleles and unknown functional loci. The $\beta$-AR gene haplotype maps and marker panels provide a basis for future studies to investigate the role of genetic variation in physiology and pathophysiology related to $\beta$-AR function.

Table 5 Effect of functional markers on haplotype diversity

\begin{tabular}{|c|c|c|c|c|c|}
\hline Gene & Variation & $\begin{array}{l}\text { Marker } \\
\text { frequency }\end{array}$ & $\begin{array}{l}\text { Haplotype } \\
\text { diversity } \\
\text { with } \\
\text { marker }\end{array}$ & $\begin{array}{l}\text { Haplotype } \\
\text { diversity } \\
\text { without } \\
\text { marker }\end{array}$ & $\begin{array}{l}\text { Haplotyp } \\
\text { diversity } \\
\text { without } \\
\text { both } \\
\text { markers }\end{array}$ \\
\hline \multicolumn{6}{|c|}{ (a) In Caucasians } \\
\hline \multirow[t]{2}{*}{$A D R B 1$} & Gly49Ser & 0.07 & 0.59 & 0.59 & 0.59 \\
\hline & Gly389Ala & 0.34 & 0.59 & 0.59 & 0.59 \\
\hline \multirow[t]{2}{*}{ ADRB2 } & Gly16Arg & 0.34 & 0.77 & 0.77 & 0.77 \\
\hline & Gln27Glu & 0.38 & 0.77 & 0.77 & 0.77 \\
\hline$A D R B 3$ & Trp64Arg & 0.08 & 0.14 & 0.14 & \\
\hline
\end{tabular}

(b) In African Americans

\begin{tabular}{llllll} 
ADRB1 & Gly49Ser & 0.26 & 0.78 & 0.78 & 0.77 \\
& Gly389Ala & 0.43 & 0.78 & 0.78 & 0.77 \\
ADRB2 & Gly16Arg & 0.45 & 0.78 & 0.78 & 0.70 \\
& Gln27Glu & 0.19 & 0.78 & 0.78 & 0.70 \\
ADRB3 & Trp64Arg & 0.17 & 0.51 & 0.51 & \\
\hline
\end{tabular}

Table $4 R^{2}$ values for functional markers versus noncoding SNPs

\begin{tabular}{|c|c|c|c|c|c|c|c|c|c|c|}
\hline \multicolumn{11}{|c|}{ (a) For $A D R B 1$ haplotype block } \\
\hline Caucasians & 1 & 2 & 3 & 4 & 5 & 6 & 7 & & & \\
\hline Gly49Ser (Marker \#3) & 0.04 & 1.00 & - & 0.04 & 1.00 & 1.00 & 0.83 & & & \\
\hline Gly389Ala (Marker \#4) & 0.84 & 0.04 & 0.04 & - & 0.04 & 0.04 & 0.03 & & & \\
\hline \multicolumn{11}{|l|}{ African Americans } \\
\hline Gly49Ser (Marker \#3) & 0.13 & 0.71 & - & 0.26 & 0.13 & 0.13 & 0.60 & & & \\
\hline Gly389Ala (Marker \#4) & 0.59 & 0.11 & 0.26 & - & 0.03 & 0.03 & 0.21 & & & \\
\hline \multicolumn{11}{|c|}{ (b) For $A D R B 2$ haplotype block } \\
\hline Caucasians & 2 & 3 & 4 & 5 & 6 & 7 & 8 & 9 & 10 & 11 \\
\hline Gly16Arg (Marker \#7) & 0.83 & 0.32 & 0.30 & 0.33 & 0.33 & - & 0.32 & 0.13 & 0.01 & 0.07 \\
\hline Gln27Glu (Marker \#8) & 0.38 & 0.96 & 0.94 & 0.92 & 0.91 & 0.32 & - & 0.23 & 0.27 & 0.14 \\
\hline African Americans & 2 & 3 & 4 & 5 & 6 & 7 & 8 & 9 & 10 & \\
\hline Gly16Arg (Marker \#7) & 0.22 & 0.06 & 0.07 & 0.07 & 0.07 & - & 0.19 & 0.31 & 0.50 & \\
\hline Gln27Glu (Marker \#8) & 0.02 & 0.23 & 0.22 & 0.22 & 0.22 & 0.19 & - & 0.14 & 0.08 & \\
\hline \multicolumn{11}{|c|}{ (c) For $A D R B 3$ haplotype block } \\
\hline Caucasians & 1 & 2 & 3 & 4 & 5 & 6 & & & & \\
\hline Trp64Arg (Marker \#5) & 1.00 & 1.00 & 1.00 & 1.00 & - & & & & & \\
\hline \multicolumn{11}{|l|}{ African Americans } \\
\hline Trp64Arg (Marker \#6) & 0.94 & 0.01 & 0.33 & 0.95 & 0.85 & - & & & & \\
\hline
\end{tabular}




\section{Acknowledgements}

We are grateful to Dr Alec Roy for a subset of his population dataset and to Longina Akhtar for assistance with cell culture. Supported by NIH Intramural Grants Z01 DE00366 and Z01 AA000301, and the Comprehensive Neuroscience Program Grant USUHS G192BR-C4 (Henry Jackson Foundation).

\section{References}

1 De Blasi A: Beta-adrenergic receptors: structure, function and regulation. Drugs Exp Clin Res 1990; 16: 107-112.

2 Arner P: Adrenergic receptor function in fat cells. Am J Clin Nutr 1992; 55: 228S-236S.

3 Tashkin DP, Conolly ME, Deutsch RI, Hui KK, Littner M, Scarpace P: Subsensitization of beta-adrenoceptors in airways and lymphocytes of healthy and asthmatic subjects. Am Rev Respir Dis 1982; 125: 185-193.

4 Rozec B, Noireaud J, Trochu JN, Gauthier C: Place of beta 3adrenoceptors among other beta-adrenoceptor subtypes in the regulation of the cardiovascular system. Arch Mal Coeur Vaiss 2003; 96: 905-913.

5 Strosberg AD: Structure, function, and regulation of the three beta-adrenergic receptors. Obes Res 1995; 3: 501S-505S.

6 Maqbool A, Hall AS, Ball SG, Balmforth AJ: Common polymorphisms of $\beta 1$-adrenoceptor: identification and rapid screening assay. Lancet 1999; 353: 897.

7 Wagoner LE, Craft LL, Zengel P et al: Polymorphisms of the beta1-adrenergic receptor predict exercise capacity in heart failure. Am Hear J 2002; 144: 840-846.

8 Iwai C, Akita H, Shiga N et al: Suppressive effect of the Gly389 allele of the beta1-adrenergic receptor gene on the occurrence of ventricular tachycardia in dilated cardiomyopathy. Circ J 2002; 66: $723-728$.

9 Stanton T, Inglis GC, Padmanabhan S, Dominiczak AF, Jardine AG, Connell JM: Variation at the beta-1 adrenoceptor gene locus affects left ventricular mass in renal failure. J Nephrol 2002; 15: $512-518$.

10 Johnson JA, Zineh I, Puckett BJ, McGorray SP, Yarandi HN, Pauly DF: Beta 1-adrenergic receptor polymorphisms and antihypertensive response to metoprolol. Clin Pharmacol Ther 2003; 74: 44-52.

11 Xie HG, Dishy V, Sofowora G et al: Arg389Gly beta 1adrenoceptor polymorphism varies in frequency among different ethnic groups but does not alter response in vivo. Pharmacogenetics 2001; 11: 191-197.

12 O'Shaughnessy KM, Fu B, Dickerson C, Thurston D, Brown MJ: The gain-of-function G389R variant of the beta1-adrenoceptor does not influence blood pressure or heart rate response to betablockade in hypertensive subjects. Clin Sci (Lond) 2000; 99: 233-238.

13 Ryden M, Hoffstedt J, Eriksson P, Bringman S, Arner P: The Arg 389 Gly beta1-adrenergic receptor gene polymorphism and human fat cell lipolysis. Int J Obes Relat Metab Disord 2001; 25: 1599-1603.

14 Dionne IJ, Garant MJ, Nolan AA et al: Association between obesity and a polymorphism in the beta(1)-adrenoceptor gene (Gly389Arg ADRB1) in Caucasian women. Int J Obes Relat Metab Disord 2002; 26: 633-639.

15 Reihsaus E, Innis M, MacIntyre N, Liggett SB: Mutations in the gene encoding for $\beta 2$-adrenergic receptor in normal and asthmatic subjects. Am J Respir Cell Mol Biol 1993; 8: 334-339.

16 Tomaszewski $\mathrm{M}$, Brain NJ, Charchar FJ et al: Essential hypertension and beta2-adrenergic receptor gene: linkage and association analysis. Hypertension 2002; 40: 286-291.

17 Yoshida N, Nishimaki Y, Sugiyama M et al: SNP genotyping in the beta(2)-adrenergic receptor by electronic microchip assay, DHPLC, and direct sequencing. J Hum Genet 2002; 47: $500-503$
18 Green SA, Turki J, Hall IP, Liggett SB: Implications of genetic variability of human beta 2 -adrenergic receptor structure. Pulm Pharmacol 1995; 8: 1-10.

19 Ellsworth DL, Coady SA, Chen W et al: Influence of the beta2adrenergic receptor Arg16Gly polymorphism on longitudinal changes in obesity from childhood through young adulthood in a biracial cohort: the Bogalusa Heart Study. Int J Obes Relat Metab Disord 2002; 26: 928-937.

20 Garenc C, Perusse L, Chagnon YC et al: Effects of beta2-adrenergic receptor gene variants on adiposity: the HERITAGE Family Study. Obes Res 2003; 11: 612-618.

21 Chang TJ, Tsai MH, Jiang YD et al: The Arg16Gly polymorphism of human beta2-adrenoreceptor is associated with type 2 diabetes in Taiwanese people. Clin Endocrinol (Oxf) 2002; 57: 685-690.

22 Buscher R, Eilmes KJ, Grasemann $\mathrm{H}$ et al: Beta2 adrenoceptor gene polymorphisms in cystic fibrosis lung disease. Pharmacogenetics 2002; 12: 347-353.

23 Jindra A, Horky K, Peleska J et al: Association analysis of Arg16Gly polymorphism of the beta2-adrenergic receptor gene in offspring from hypertensive and normotensive families. Blood Press 2002; 11: $213-217$.

24 Bruck H, Leineweber K, Buscher R et al: The Gln27Glu beta2adrenoceptor polymorphism slows the onset of desensitization of cardiac functional responses in vivo. Pharmacogenetics 2003; 13: $59-66$.

25 Taylor DR, Kennedy MA: Genetic variation of the beta(2)adrenoceptor: its functional and clinical importance in bronchial asthma. Am J Pharmacogenomics 2001; 1: 165-174.

26 Shachor J, Chana Z, Varsano S et al: Genetic polymorphisms of the beta-2 adrenergic receptor in Israelis with severe asthma compared to non-asthmatic Israelis. Isr Med Assoc J 2003; 5: $821-824$.

27 Iwamoto N, Ogawa Y, Kajihara S et al: Gln27Glu beta2-adrenergic receptor variant is associated with hypertriglyceridemia and the development of fatty liver. Clin Chim Acta 2001; 314: 85-91.

28 Gonzalez Sanchez JL, Proenza AM, Martinez Larrad MT et al: The glutamine 27 glutamic acid polymorphism of the beta2adrenoceptor gene is associated with abdominal obesity and greater risk of impaired glucose tolerance in men but not in women: a population-based study in Spain. Clin Endocrinol (Oxf) 2003; 59: 476-481.

29 Duarte NL, Colagiuri S, Palu T, Wang XL, Wilcken DE: Obesity, Type II diabetes and the beta 2 adrenoceptor gene Gln27Glu polymorphism in the Tongan population. Clin Sci (Lond) 2003; 104: $211-215$.

30 Walston J, Silver K, Bogardus C et al: Time of onset of non-insulindependent diabetes mellitus and genetic variation in the beta 3adrenergic-receptor gene. $N$ Engl J Med 1995; 333: 343-347.

31 Yoshida N, Sakane N, Umekawa T: Mutation of beta-3-adrenergicreceptor gene and response to treatment of obesity. Lancet 1995; 346: $1433-1434$.

$32 \mathrm{Li}$ LS, Lonnqvist $\mathrm{F}$, Luthman $\mathrm{H}$, Arner P: Phenotypic characterization of the Trp64Arg polymorphism in the beta 3adrenergic receptor gene in normal weight and obese subjects. Diabetologia 1996; 39: 857-860.

33 Gabriel SB, Schaffner SF, Nguyen $\mathrm{H}$ et al: The structure of haplotype blocks in the human genome. Science 2002; 296: $2225-2229$.

34 Shi MM, Myrand SP, Bleavins MR, de la Iglesia FA: High throughput genotyping for the detection of a single nucleotide polymorphism in $\mathrm{NAD}(\mathrm{P}) \mathrm{H}$ quinone oxidoreductase (DT diaphorase) using TaqMan probes. Mol Pathol 1999; 52: 295-299.

35 Stephens M, Smith NJ, Donnelly P: A new statistical method for haplotype reconstruction from population data. Am J Hum Genet 2001; 68: 978-989.

36 Long JC, Williams RC, Urbanek M: An E-M algorithm and testing strategy for multiple locus haplotypes. Am J Hum Genet 1995; 56: 799-810.

37 Ke X, Cardon L: Efficient selective screening of haplotype tag SNPs. Bioinformatics 2003; 19: 287-288. 
38 Maqbool A, Hall AS, Ball SG, Balmforth AJ: Common polymorphisms of beta1-adrenoceptor: identification and rapid screening assay. Lancet 1999; 353: 897.

39 Tesson F, Charron P, Peuchmaurd M et al: Characterization of a unique genetic variant in the beta1-adrenoceptor gene and evaluation of its role in idiopathic dilated cardiomyopathy. CARDIGENE Group. J Mol Cell Cardiol 1999; 5: 1025-1032.

40 Lynch RA, Wagoner L, Li S, Sparks L, Molkentin J, Dorn JW: Novel and nondetected human signaling protein polymorphisms. Physiol Genomics 2002; 10: 159-168.
41 Yoshida N, Nishimaki Y, Sugiyama M et al: SNP genotyping in the beta(2)-adrenergic receptor by electronic microchip assay, DHPLC, and direct sequencing. J Hum Genet 2002; 47: 500-503.

42 Borjesson M, Magnusson Y, Hjalmarson A, Andersson B: A novel polymorphism in the gene coding for the beta(1)-adrenergic receptor associated with survival in patients with heart failure. Eur Heart J 2000; 22: 1853-1858.

43 Silver K, Walston J, Yang Y et al: Molecular scanning of the beta-3adrenergic receptor gene in Pima Indians and Caucasians. Diabetes Metab Res Rev 1999; 15: 175-180. 